\title{
How business accelerators impact startup's performance: Empirical insights from the dynamic capabilities approach
}

\author{
Celia Polo García-Ochoa (iD, Carmen De-Pablos-Heredero(D), \\ Francisco José Blanco Jiménez iD \\ Rey Juan Carlos University (Spain) \\ c.polog@alumnos.urjc.es,carmen.depablos@urjc.es,francisco.blanco@urjc.es
}

Received July, 2020

Accepted November, 2020

\begin{abstract}
Purpose: Accelerators are seen as powerful entities that provide critical support to startups in their development. However, little is known about the acceleration practices by which they help their startups. The present study has as its aim to investigate whether business accelerators do assist their startups in the generation of their dynamic capabilities and in their performance and which processes and organizational routines of accelerators programs become effective drivers.
\end{abstract}

Design/methodology: Drawing from the dynamic capability perspective, this empirical research explores the impact of business acceleration programs in their startups by applying a Canonical discriminant analysis using data from 24 Spanish business accelerators.

Findings: This study reveals that certain accelerators practices indeed enhance startups' dynamic capabilities. Further, absorption, integration, and innovation capabilities had a positive influence on startups' performance while sense the market capability showed a negative one. These findings enable us to identify which business acceleration practices lead to better startups' performance improvements.

Research limitations/implications: This is a preliminary attempt to help in the untangling of the dynamic capability and the business incubation black box. The cross-sectional design of the study and the fact that the data was gathered from a single country and based on survey results in bias and in a limited generalization of its findings.

Practical implications: This research can help decision makers' in business accelerators to put in practice organizational mechanisms aimed to be more successful in their objectives.

Originality/value: This study is pioneer to empirically analysis the relationship between business accelerators' practices and the generation of dynamic capabilities.

Keywords: Accelerators, Entrepreneurship, Start-ups, Dynamic capabilities

Jel Codes: L26, M13 


\section{To cite this article:}

Polo García-Ochoa, C., De-Pablos-Heredero, C., \& Blanco Jiménez, F.J. (2020). How business accelerators impact startup's performance: Empirical insights from the dynamic capabilities approach. Intangible Capital, 16(3), 107-125. https://doi.org/10.3926/ic.1669

\section{Introduction}

Business accelerators are organizations aimed at enhancing the capabilities of startups through educational programming and processes (Clarysse, Wright, \& Hove, 2015; Pauwels, Clarysse, Wright \& Van Hove, 2016). They are structured to provide an intensive, fixed-term educational program which includes mentoring and networking for the cohort of startups selected, to help them reach key milestones (Hallen et al., 2019). The processes embedded in these programs have the capacity to facilitate growth of startups. They play a "transformative role" in the development of new ventures (Goswami, Mitchell \& Bhagavatula, 2018). All in all, one can argue that business accelerators may foster the development of startups' dynamic capabilities, defined as: acquired abilities which enable firms to integrate, develop and reconfigure both internal and external resources and ordinary capabilities in the manner regarded as appropriate by the entrepreneur (Madsen, 2010)

The importance of the development of dynamic capabilities by new firms is recognized in the literature (Jones, Macpherson \& Jayawarna, 2013; Newbert, 2005; Zahra, Sapienza \& Davidsson, 2006). They allow new firms to sense and respond to changing market conditions and operational or strategic crises (Jones et al., 2013) and thus, they improve the likelihood of sustaining their growth (Telussa, Stam \& Gibcus, 2006) and maximizing their goals (Zahra, Sapienza \& Davidsson, 2006). They can't be bought, they are created and developed over time by organizational processes adopted by start-ups (Corner \& Wu, 2012; Teece, Pisano \& Shuen, 1997) and may be learnt (Eisenhardt \& Martin, 2000; Teece et al., 1997; Zahra et al., 2006).

To assess the "prodigious ability" of business accelerators to support startups' growth (Brown, Mawson, Lee \& Peterson, 2019), it is therefore critical to study whether and how the processes embedded in business accelerators programs influence the development of startups' dynamic capabilities. Therefore, the aim of this paper is to study whether business accelerators do assist their accelerated startups in the generation of dynamic capabilities. The paper is organized as follows: First, we develop a theoretical framework and the research hypotheses. Then, we describe the methodology used in this study followed by the results obtained using primary data from 24 Spanish accelerators, one of the leading European countries for nurturing startups (Mobile World Congress, 2019). In the last section, the empirical findings are discussed, the study's limitations are also addressed, and future lines of research are finally described.

This study contributes to the literature in different ways. First, there is a lack of a consistent theoretical perspective to study accelerators (Pauwels et al., 2016) and also, more empirical work on the determinants of startup's performance is needed (Hausberg \& Korreck, 2018; Smith \& Hannigan, 2015). In this paper, a deep understanding of how multiple accelerator's actions may impact the performance of startups is built. The dynamic capabilities approach is used to understand how processes and organizational routines of accelerators programs become effective drivers for superior performance. To our knowledge, this is the first study that analyses this relationship. Therefore, our study fills an important gap in the literature showing how concepts from the dynamic capabilities' approach can strengthen the accelerators literature. Data enabled us for the first time to connect specific organizational actions oriented to the deployment of dynamic capabilities with results in the process of venture creation within an accelerator.

Second, we explore how business accelerators support startups' growth, answering recent calls (Gonzalez-Uribe \& Leatherbee, 2016; Smith \& Hannigan, 2015; Wright \& Drori, 2018) for in-depth examination of the mechanisms through which accelerators foster the development of startups. Our results show that business accelerators can enhance the development of startup's DC and as a result, startup's performance, revealing a new potential role of business accelerators previously not acknowledged. 
Also, we extend the research on dynamic capabilities to startups, a field with limited academic research (Deeds, DeCarolis \& Coombs, 1999; Newbert, 2005), which represents a theoretical contribution to the DC perspective by enhancing our understanding of the direct effects of this view across entrepreneurial settings.

Finally, highlighting which specific accelerators' practices have positive effects in startups has practical implications for policymakers and business accelerator directors. In this sense, this research can help decision makers' in business accelerators to put in practice organizational mechanisms aimed to be more successful in their objectives.

\section{Theoretical framework and hypotheses}

Our theoretical framework to develop a better understanding of how business accelerators impact their accelerated startups draws from the Dynamic Capabilities approach (Jones, Macpherso \& Jayawarna, 2014; Teece et al., 1997; Zahra et al., 2006). This perspective emerges in response to shortcomings of the classic ResourceBased View (Wernerfelt, 1984) concerning a static approach and insufficient basis for explaining the strategic adaptation of firms when business environment shifts (Eisenhardt \& Martin, 2000; Winter, 2003). The dynamic capabilities view extends resource-based view by addressing the evolutionary nature of firm resources and capabilities in relation to environmental changes and enabling identification of firm processes that are critical to firm evolution (Wang \& Ahmed, 2007) and also, to value creation potential (Wójcik, 2015).

Dynamic capabilities are acquired abilities which enable firms to integrate, develop and reconfigure internal and external resources and ordinary capabilities in the manner, assumed as appropriate by the entrepreneur (Madsen, 2010). They are thus organizational and strategic routines developed through organizational learning and molded by path dependencies, complementary assets, and industry opportunities (Teece et al., 1997) by which managers recombine their resources to generate new value-creating strategies as markets emerge, collide, split, evolve, and die" (Eisenhardt \& Martin, 2000, p. 1107). As a result, dynamic capabilities have the potential to influence a firm’s performance (Hernández-Linares, Kellermanns \& López-Fernández, 2018).

In the entrepreneurship context, the ability to generate these capabilities at an early stage will improve the likelihood of a sustained growth for the new firm (Telussa et al., 2006) as they help them face their liabilities and challenges Jones et al., 2013. For example, Wu (2007) confirmed that resource availability and their integration and reconfiguration played a critical role to enhance the performance of the high-tech startups he studied. Also, Macpherson, Jones, and Zhang (2004) case study of a startup, identifies dynamic capabilities as a key antecedent to innovation and growth. Their investigation shows how a firm's resource capacity is expanded by building an effective business network and also, how this network allows to respond flexibly to customers' needs and to exploit opportunities quickly. The underlying assumption is that startups that use dynamic capabilities, will maximize their goals (Zahra et al. 2006) and enhance their performance outcomes (Hernández-Linares et al., 2018).

Business accelerators are a notable phenomenon in the startup's landscape (Wright \& Drori, 2018). They provide startups with a time-limited, cohort-based value-adding program of monitoring, mentoring and networking (Clarysse et al., 2015; Miller \& Bound, 2011). These programs orchestrate resources and deploy strategic processes to enhance startups' capabilities and expose them to markets and institutions with the objective (Wright \& Drori, 2018) of facilitating their development and improving their chances to succeed (Pauwels et al. 2016).

Given that business accelerators are organizations aimed at supporting startups by providing them the inputs needed to enhance their performance and succeed (Goswami et al., 2018; Pauwels et al., 2016; Yusubova \& Clarysse, 2016), one could argue that by helping startup generate their dynamic capabilities, they would be achieving their ultimate goals. Therefore, we assume a direct relationship between business accelerators and the generation of startups' dynamic capabilities and thus, in their performance.

Even though there is evidence which demonstrates that business accelerators can have positive effects on startups' performance (e.g. Battistella, De Toni \& Pessot, 2017; Hallen et al., 2019; Shankar \& Shepherd, 2019; 
Smith \& Hannigan, 2015), there remains a limited understanding of the processes and practices by which they accomplish these outcomes (Wright \& Drori, 2018).

According to Hackett and Dilts (2004), the dynamic capabilities can be viewed as an appropriate framework to "facilitate inquiries into the way in which business incubators build new venture development resources and capabilities and allocate these resources to the transformation of startups into value-producers" (Hackett \& Dilts, 2004, p. 46). Also, they mentioned that "a dynamic capabilities approach would serve as a strong theoretical foundation for studies centered on development strategies of incubatees, and new ventures writ large." (Hackett \& Dilts 2004, p. 46).

Both business incubators and accelerators have been acknowledged by policymakers, private investors, corporations and academics, as effective ways to support the creation of new firms and deal with their needs in their early stages (Pauwels et al., 2016; Yang, Kher \& Lyons, 2018) so, we believe that the dynamic capabilities view is also an appropriate lens to analyse the processes embedded in business accelerator programs and explore their outcomes.

In line with recent studies (Hernández-Linares et al., 2018; Hidalgo-Peñate, Padrón-Robaina \& Nieves, 2019; Rao, Chandy \& Prabhu, 2008) we adopt a multidimensional view of dynamic capabilities which focus on four types of dynamic capabilities. Specifically, we propose that the processes and resources embedded in business accelerator programs contribute to the generation of the dynamic capabilities of sensing the market, absorption, integration, and innovation in their startup's portfolio.

Although this study is pioneer to link business accelerators' practices and the generation of dynamic capabilities, there are recent studies that support the relationship proposed between these four dynamic capabilities and firm's performance (e.g. Bastanchury-Lopez, De Pablos Heredero, García-Martínez \& Martín-Romo Romero, 2019; Blanco-Callejo \& De-Pablos-Heredero, 2019; De Pablos Heredero, Fern \& Blanco-Callejo, 2017; De Pablos Heredero, García \& Martín-Romo, 2019; De-Pablos-Heredero \& Lopez Berzosa, 2012) These studies support our argument that these dynamic capabilities need to be developed by startups through business acceleration processes in order to succeed in the market.

We outline the main effects of business accelerators on startup's development based on the four dynamic capabilities as well as their effects on startups' performance.

\subsection{Sensing the market capability}

Not all the opportunities are viable (Song, Podoynitsyna, Van Der Bij \& Halman, 2008) so being able to identify and select the right ones for new businesses development is among the most important abilities of a successful entrepreneur (Ardichvili, Cardozo \& Ray, 2003). When an opportunity shows up, entrepreneurs are expected to figure out how to interpret new events and developments, which technologies to pursue, and which market segments to target (Teece, 2007). Thus, to take advantage of these potential benefits and turn them into realized outcomes, it is necessary to develop a sensing the market capability (Zhang \& Wu, 2013). The sensing capability is defined as the firm's ability to identify, interpret and assess opportunities in the environment (Pavlou \& El Sawy, 2011; Teece, 2012). This capability requires being continuously probing markets and listening to customers in order to understand latent demand, as well as the evolution of industries and markets, and the supplier and competitor responses (Leih, Linden \& Teece, 2014). This means that information alone does not result in better outcomes, firms need to put in place various processes "to gather, filter, and make sense of information" from both inside and outside the enterprise (Teece, 2007, p. 1326). Also, it has a positive influence on achieving more innovative products, faster speed to market (Zhang \& Wu 2013) and improving new venture performance (Jiao, Alon \& Cui, 2011). However, startups lack of experience to interact with their environment and information asymmetries (Garcés \& Mkheidze, 2018). Moreover, startups do not tend to predict accurately opportunities or how to address them, so as a result they need to adapt and modify their approach over time (Sommer, Loch \& Dong, 2008). 
Participation in business accelerators programs force startups to deal with the challenges regarding the viability of their business models by guiding and helping startups refine and advance in their product-market concept (Kohler, 2016; Liao, Kickul \& Ma, 2009; Wright \& Drori, 2018; Yang et al., 2018). Programs are structured in a way that allows startups to focus on solving problems related to technology/product issues and gaining a deeper understanding of their clients/market (Wright \& Drori, 2018).

It infers that business accelerators help their startups to develop their capability of sensing the market and thus improve their performance by promoting the use of a systematic process, identifying and assessing firm's business opportunities, enabling them to produce the right products or services, targeting the right markets, addressing consumer needs, and leveraging the opportunity found. Accordingly, we hypothesize the following:

\section{H1: Accelerator influences the relationship between startup's sensing the market capability and its performance.}

\subsection{Absorptive capability}

In general, knowledge is power to all firms. However, the firms' capacity to perform depends on the relevance of this knowledge to the firm and how it is processed (Debrulle, 2012). As such, a firm's absorptive capability or its ability to identify new external information, assimilate and use it for organizational advantage is key to strengthen their competitive position and thus, to improve their survival (Keh, Nguyen \& Ng, 2007; Lane \& Lubatkin, 1998; Lumpkin \& Katz, 2007; Sapienza, Autio, George \& Zahra, 2006; West \& Noel, 2009; Zahra \& George, 2002)

This capability is especially important for startups (Debrulle, 2012). Because they are challenged by a lopsided knowledge base, few capabilities and a limited capacity to develop them are found, hence they present a higher need for new knowledge (Debrulle, 2012). The startups' absorptive capability can help to generate this required knowledge. A startup's absorptive capability is thus the processes to recognize the value of new external knowledge, to acquire it, and to transform it into productive, valuable, and firm- specific learning outcomes directly relevant to its activities (Cohen \& Levinthal, 1990; Lane \& Lubatkin, 1998). This utilization involves a journey from the identification and acquisition of external knowledge, through its assimilation and to the understanding of its application in a commercially viable way (Cohen \& Levinthal, 1990). The greater the extent to which startups have clear routines through which knowledge is accessed, stored, and transferred in them, the greater is their absorptive capability (Debrulle, 2012).

Business accelerators programs are focused on intense education, interaction, and monitoring (Pauwels et al., 2016). The educational support includes sessions with experts designed to provide specific knowledge related to managing and operating a new venture firm (Wright \& Drori, 2018). There are also other learning opportunities related to learning from cohorts, mentors or stakeholders (Goswami et al., 2018). Mentorship is "a key ingredient" for a successful startup (Hoffman \& Radojevich-Kelley, 2012, pp 58). Mentoring services vary from individual sessions on an as-needed basis to programmed group-meetings. These individual and group advising sessions provide startups with business assistance, guidance to solve problems, analyse failures, learn from peers who have overcome similar obstacles and enable the accelerator management team or mentors to monitor their progress (Pauwels et al., 2016; Stross, 2012). By doing this, business accelerators help startups to absorb and apply the knowledge they gather through the program as they allow them to adequately understand and process this knowledge for its future application (Chen, Lin \& Chang, 2009; Lumpkin \& Katz, 2007). Also, startups are exposed to intense and close interactions to varied communities of stakeholders that allows them to get target feedback (Wright \& Drori, 2018).

These business accelerator routines facilitate the startups' knowledge acquisition. They expose them to new and adequate information, helping them share, interpret and apply it rapidly, enabling them to enhance their absorptive capability, maximizing the startups' efforts to improve their performance. We therefore suggest:

\section{H2: Accelerator influences the relationship between startup's absorptive capability and its performance}




\subsection{Integration capability}

As an emerging business gradually becomes defined, continuous adaptation and market validation is needed (Roseno, Enkel \& Mezger, 2013). Thus, the new business creation process is not a straightforward process as it involves a great deal of iterations (Juntunen, 2017). These iterations or reconfigurations rely on the firm's capability to integrate new resources and assets including knowledge with those internally generated to revamp routines and practices (Pavlou \& El Sawy, 2011). Hence, integrative capability helps startups achieve a positive interaction among different resources by converting them into comprehensive sets of value-creating organizational skills aligned with external environment (Wang \& Ahmed, 2004)

As mentioned before, one of the most valuable aspects of business accelerator programs is the provision of mentoring to startups (Battistella et al., 2017). Mentoring is a learning and coaching process where a reciprocal relationship is built between mentor and startup while focusing on achievement (Wright \& Drori, 2018). Mentors are experienced entrepreneurs or experts who share their knowledge and skills with startups (Cohen \& Hochberg, 2014). Within mentoring routines, startups learn and progress through conversations with feedback loops between mentor and entrepreneur that foster the development of the startup toward their full potential (Fowle \& Tyne, 2017). By doing so, startups are involved in cycles of constant monitoring and adjustment by combining their new and existing knowledge in solutions to confront their obstacles quicker and solve uncertainties as they emerge. This intense interaction with the mentors leads to a continuous knowledge integration and its systematic application that allows startups teams to explore different options and to adapt their business model in order to create a profitable business.

Beyond mentors, accelerators' teams also routinely monitor startups progress through dedicated follow-ups sessions or evaluation times (Cohen, 2013; Polo-García-Ochoa, 2020). In these events, startups report their progress and challenges forcing them to show progress and evolve in each session due to what some authors call the "the power of shame avoidance" (Stross, 2012). This prods them to be willing to learn and constantly integrating that learning into their working routines as they would not want be embarrassed themselves by showing little progress (Stross, 2012). Thanks to these routines of continuous evaluation and surveillance within a short period of time, the integration capability of startups is enhanced. Thus, we hypothesize:

\section{H3: Accelerator influences the relationship between startup's integration capability and its performance}

\subsection{Innovation capability}

A firm's ability to innovate is a critical factor for its survival and success (Akman \& Yilmaz, 2008; Monferrer, Blesa \& Ripollés, 2013; Wang \& Ahmed, 2004). Innovation capability perspective focuses on the outcomes of organizations (i.e., products, services, markets, business models) (Saunila \& Ukko, 2014). However, the innovation capability of a company can be understood from a more global perspective taking into account all its dimensions. In this sense, the innovation capability of a firm is its ability to develop new products and markets, by aligning an innovative strategic orientation with innovative processes and behaviors (Wang \& Ahmed, 2004).

Based on the above definition, innovation capability is a multi-faceted construct (Saunila \& Ukko, 2014) that goes from technological to human aspects (Prajogo \& Ahmed, 2006). Because the processes and resources that startups experience and acquire throughout their lifecycle within a business accelerator, their innovation capability is enhanced.

Entrepreneurs are vehicles to make innovation happen (Gonthier \& Chirita, 2019). However, creative ideas by themselves have no value, those ideas need to be commercially viable in order to be successful. Most of new ideas are not commercially viable at the beginning, entrepreneurs need to put in place processes to search for a profitable business from the very initial stages (Blank \& Dorf, 2012; Ries, 2013).

According to Trimi and Berbegal-Mirabent (2012), one of the main reasons for start-ups failure is their lack of processes to do so. Also, they are characterized by a chaotic and informal structure way of working (Wright \& Drori, 2018). 
Business accelerators foster an innovation culture where startups understand the importance to work towards the commercial viability of their innovations since the very beginning. Accelerators encourage startups to adopt specific management methodologies that help startups manage their contingencies and successfully develop their innovative products and services through strategic oriented processes (Barrehag et al., 2012; Trimi \& BerbegalMirabent, 2012). Alike traditional ways, these methods apply an iterative approach and a trial-and-error philosophy for validating business models, the appropriateness of specific products or services to market or for providing frugal working routines to transform innovations into scalable solutions (Gonthier \& Chirita, 2019; Trimi \& Berbegal-Mirabent, 2012).

Most of business accelerators partner with stakeholders to offer deals to their portfolio companies. These deals are established with many companies at the forefront of technology which supports startups' development process through different means such as free services or special access. These deals facilitate the technological requirements and obstacles constraints of startups' when creating new products or processes faster than outside of business accelerators would do.

Innovation capability also requires an openness and collaboration culture (Skarzynski \& Gibson, 2008) where the willingness to take risks and to exchange ideas are promoted (Wan, Ong \& Lee, 2005). The supportive peer-topeer, entrepreneurial working environment (Cohen, Fehder, Hochberg \& Murray, 2019; Cohen \& Hochberg, 2014) in which startups are embedded during the acceleration program leverage startups' innovation capability. In fact, as Y Combinator highlights in its web, they fund startups in batches because it works better for everyone. "It's more efficient for us, but also better for the startups, who probably end up helping one another at least as much as we help them" (Y Combinator, 2020). Business accelerators provide a working space to their startups to work alongside other entrepreneurs instead of in isolation and establish communication mechanisms for them to access their business accelerator networks (Polo García-Ochoa, 2020), which reflects in startups' innovation capability (Konsti-Laakso, Pihkala \& Kraus, 2012).

By offering processes that help startups to adopt and internalize working and innovative thinking habits, a working space to progress together and mechanisms to exchange information, business accelerators are fostering the underpinning activities that enable the enhancement of startups' innovation capability. We therefore suggest:

\section{H4: Accelerator influences the relationship between startup's innovation capability and its performance}

\section{Method}

\subsection{Sample and data collection}

We conducted an empirical study with Spanish business accelerators as the primary research subjects. The selection of Spain as a country base is relevant given the acknowledgement of this country as one of the biggest startups' hubs on Europe (Mobile World Congress, 2019; Atomico, 2019). The lack of an official database of Spanish business accelerators, led us to use a reputable complementary source to frame our sample namely "El Referente" (Guía de Inversión para Startups, 2018-2019). To select the business accelerators that would be included in our study was a complicated exercise due to the variety of entities calling themselves business accelerators without gathering their unique features. So we restricted our sample to Spanish business accelerators which fulfill the following characteristic: A fixed-term, cohort-based program, including mentorship and educational components, that culminates in a public pitch event or demo day (Cohen, 2013; Cohen \& Hochberg 2014). So, the study population was 29 and our sample was 24 (82.75\% of the whole population of business accelerators).

Data were collected from July 2019 to January 2020 by direct questionnaires which included 19 questions on the dynamic capabilities of sensing the market, absorption, integration, and innovation.

\subsection{Selection of set of dynamic capabilities indicators}

The lack of prior research into the themes connected to dynamic capabilities and accelerators motivated the authors to use a Delphi approach as an appropriate way to obtain information (Varela-Ruiz \& Díaz-Bravo, 2012). 
This qualitative, consensus and participatory methodology is described by Torrado-Fonseca and Reguant-Álvarez (2016) amongst others, and applied in social sciences studies (Dana \& Wright, 2008; Gartner, 1990; Martínez García, Padilla Carmona \& Suárez Ortega, 2019; Pandza \& Holt, 2007). The Delphi process was conducted from January 2019 to March 2019 and enrolled the experience of startup founders, managers or professionals related to startups or businesses accelerators. They helped us to build a list of specific routines embedded in business acceleration programs which might impact the development of the dynamic capabilities of sensing the market, absorption, integration, and innovation in their startup's portfolio.

In the first step, relevant practices linked to each dynamic capability were identified and selected. Firstly, a preselection of business accelerators practices was conducted according to their relevance to favor dynamic capability development. The pre-selection was based on an extensive literature review from Hallen et al., (2019), Teece (2007), Pavlou and El Sawy (2011) and Barrehag et al. (2012) amongst others. Finally, 29 items were preselected representing the different accelerator's routines divided into 4 sections, each focusing on a dynamic capability. Also, an open-ended question was included to add further comments as necessary at the end of each section. Subsequently, the selection process consists of experts' judgments by means of successive iterations of questionnaire, to show convergence of opinions and to identify dissent or non-convergence. By conducting telephone, mail or face to face interviews with 16 experts, each pre-selected item was analysed and addressed according to its relevance in startups' dynamic capabilities generation in a business accelerator context. A second round was sent with descriptive information from the previous set of responses to each expert to reconsidering their judgment and also, newly questions provided by them in the prior round to be assessed. The selection of the final items to be included started after having assured the adequacy and completeness of the list of preselected items and the newly suggested. This way, experts assessed each routine by a Likert scale from one to five values, where one was the least important and five the most important. To select them, two reference statistics were taken to: the mean, which should be greater than 3.5 and the median which should be greater than 3 . This ensures that all the items were considered important for all experts and for the whole sample. Then, from the items whose values met the previous criteria, we selected those items in which there was consensus. Consensus was achieved by having at least $75 \%$ of participants' votes fall within 4 and 5 values or when this does not happen, the standard deviation has to be equal or less than 0.90. Finally, from a list of 29 initial variables and 12 newly suggested variables generated in the first round, the 16 participants reached consensus on 19 different items developed by accelerators which help in the generation of startups' dynamic capabilities.

\subsection{Statistical analysis}

Four set of variables were defined: those related to sense the market capability $\left(\mathrm{S}_{\mathrm{i}}\right)$, those related to absorption capability $\left(\mathrm{A}_{\mathrm{i}}\right)$, those related to integration capability $\left(\mathrm{INT}_{\mathrm{i}}\right)$ and those related to innovation capability $\left(\mathrm{INN}_{\mathrm{i}}\right)$, as shown in Table 1. Also, the values obtained in the descriptive analysis for each variable are included. Canonical discriminant analysis was applied to analyse the relationships amongst the three four groups of variables. All statistical analyses were performed by using the software SPSS for Windows.

\section{Results}

The Table 2 shows the general results of the canonical discriminant analysis with all the model measured: model sense the market capability $\left(\mathrm{S}_{\mathrm{i}}\right)$, model absorption capability $\left(\mathrm{A}_{\mathrm{i}}\right)$, model integration capability $\left(\mathrm{INT}_{\mathrm{i}}\right)$, model innovation capability $\left(I N N_{i}\right)$ and group model $\left(\mathrm{S}_{\mathrm{i}}+\mathrm{A}_{\mathrm{i}}+\mathrm{INT}_{\mathrm{i}}+\mathrm{INN}_{\mathrm{i}}\right)$. The aim of the analysis is to determine whether the variables used in each model will discriminate between those accelerators which get more than $50 \%$ startups financed (group 2) and those which do not (group 1). In three of the five cases, discrimination among groups was relevant because the Wilks' lambda was always significant for the discriminant variables. The models $\left(\mathrm{S}_{\mathrm{i}}\right)$ and $\left(\mathrm{A}_{\mathrm{i}}\right)$ and $\left(\mathrm{S}_{\mathrm{i}}+\mathrm{A}_{\mathrm{i}}+\mathrm{INT}_{\mathrm{i}}+\mathrm{INN}_{\mathrm{i}}\right)$ classify $79.2,95.8 \%$ and $87.5 \%$ of cases correctly. Also, it can be observed that the discriminant functions are also sufficiently significant, with values of $\mathrm{p}<0.05$ in all of the cases. The three models show discriminant capability. As showed, the other two models $\left(\mathrm{INT}_{\mathrm{i}}\right)$ and $\left(\mathrm{INN}_{\mathrm{i}}\right)$ do not show discriminant capability $(\mathrm{p}>0.05)$. 


\begin{tabular}{|c|c|c|c|c|c|c|c|}
\hline Model (n) & $\begin{array}{l}\text { Eigen } \\
\text { value }\end{array}$ & $\begin{array}{l}\text { Can. } \\
\text { Corr }\end{array}$ & $\begin{array}{c}\text { Wilks' } \\
\text { lambda }\end{array}$ & Chi-square & gl & $\mathrm{p}$ & Correct \\
\hline $\begin{array}{l}\text { Sensing the market } \\
\text { variables }\left(\mathrm{S}_{\mathrm{i}}\right)\end{array}$ & 0.997 & 0.707 & 0.501 & 13.491 & 5 & 0.019 & 79.2 \\
\hline $\begin{array}{c}\text { Absorption variables } \\
\left(\mathrm{A}_{\mathrm{i}}\right)\end{array}$ & 1.828 & 0.804 & 0.354 & 19.229 & 7 & 0.008 & 95.8 \\
\hline $\begin{array}{c}\text { Integration variables } \\
\left(\mathrm{INT}_{\mathrm{i}}\right)\end{array}$ & 0.131 & 0.340 & 0.884 & 2.523 & 3 & 0.471 & 66.7 \\
\hline $\begin{array}{l}\text { Innovation variables } \\
\qquad\left(\mathrm{INN}_{\mathrm{i}}\right)\end{array}$ & 0.29 & 0.121 & 0.972 & 0.611 & 1 & 0.434 & 70.8 \\
\hline $\begin{array}{c}\text { All mean variables } \\
\left(\mathrm{S}_{\mathrm{i}}+\mathrm{A}_{\mathrm{i}}+\mathrm{INT}_{\mathrm{i}}+\mathrm{INN}_{\mathrm{i}}\right)\end{array}$ & 0.954 & 0.699 & 0.512 & 13.398 & 4 & 0.009 & 87.5 \\
\hline
\end{tabular}

Table 1. Results of canonical discriminant analyses

Also, standardized canonical coefficients (SCC) and the structure matrix were examinedto determine which variables contributed more to the group differences. Table 3 summarizes this information for the discriminant function estimated. The SCC provides an index of the importance of each predictor. Coefficients with large absolute values correspond to variables with greater discriminating ability.

In model $\left(\mathrm{S}_{\mathrm{i}}\right)$, "Teach entrepreneurs about the identification and monitoring of metrics and KPIs" $\left(\mathrm{S}_{4}\right)$ score was the strongest predictor while $\left(\mathrm{S}_{2}\right)$, "Inculcate entrepreneurs the importance of gaining real knowledge of their target market / customers" (note-sign) was next in importance as a predictor.

In the case of model $\left(\mathrm{A}_{\mathrm{i}}\right)$, "Entrepreneurs have individual sessions with mentors in their program." $\left(\mathrm{A}_{6}\right)$ score (note - sign) was the strongest predictor followed by "Review the results and metrics with each entrepreneur to belp them interpret and make decisions" $\left(\mathrm{A}_{7}\right)$ as the next variable in importance.

Finally, in model $\left(\mathrm{S}_{\mathrm{i}}+\mathrm{A}_{\mathrm{i}}+\mathrm{INT}_{\mathrm{i}}+\mathrm{INN}_{\mathrm{i}}\right)$, "Sensing the market capability." $\left(\mathrm{S}_{\mathrm{i}}\right)$ score (note - sign) was the strongest predictor while $\left(\mathrm{INT}_{\mathrm{i}}\right)$, "Integration capability" (note - sign) and $\left(\mathrm{AB}_{\mathrm{i}}\right)$, "Absorption capability" were the next variables in importance.

These variables with large coefficients stand out in each model as those that strongly predict allocation to more than $50 \%$ alumni financed or not (our indicator of accelerator performance). The rest of the variables were less successful as predictors.

Although the variables named above are those that contribute the most to discriminate, the interpretation of each one is different. The signs of standardized canonical coefficients are used to characterize the function. It indicates the direction of the relationship but, in order to interpret the direction, we need to understand where the group centroid lies (Table 6). Cases with scores near to a centroid are predicted as belonging to the class that defines that centroid. Examining the group centroids for the three models(Table 6), centroids for group 1 (less than $50 \%$ startups financed) has always positive means while the ones for group 2 (more than $50 \%$ startups financed) produces always negative ones.

This implies that in model $\left(S_{i}\right)$, group 1 was defined by the variables $S_{1}, S_{3}, S_{4}$ y $S_{5}$ while group 2 was defined by the variable $S_{2}$; in model $\left(A_{i}\right)$, group 1 was defined by the variables $A_{1}, A_{3}, A_{5}$ y $A_{7}$ and group 2 by $A_{2}, A_{4}$ and $A_{6}$, and in model $\left(S_{i}+A_{i}+I N T_{i}+I N N_{i}\right)$ group 1 was defined by the variables $S_{i}$, and group 2 by $A_{i}, I N T_{i}, I N N_{i}$.

So, in the case of the routines such us $\left(\mathrm{S}_{2}\right)$, "Inculcate entrepreneurs the importance of gaining real knowledge of their target market / customers" in model $\left(\mathrm{S}_{\mathrm{i}}\right)$, the routines "Entrepreneurs have individual sessions with mentors in their program." $\left(\mathrm{A}_{6}\right)$ and, "Facilitate the contact of the entrepreneurs with potential clients and / or specific communities" $\left(\mathrm{A}_{4}\right)$ in model $\left(\mathrm{A}_{\mathrm{i}}\right)$ and those routines related to integration $\left(I N T_{i}\right)$ and absorption capabilities $\left(A_{i}\right)$ in model $\left(S_{i}+A_{i}+I N T_{i}+I N N_{i}\right)$, if the accelerator performs these routines with a higher frequency than the average, the accelerator will be classified in group 2. 
Otherwise, a higher frequency than the average in routines such us "teach entrepreneurs about the identification and monitoring of metrics and KPIs" $\left(\mathrm{S}_{4}\right)$, "Review the results and metrics with each entrepreneur to belp them interpret and make decisions" $\left(\mathrm{A}_{7}\right)$, "Organize workshops to meet the needs / abilities of entrepreneurs" $\left(\mathrm{A}_{1}\right)$ or those relate to sense the market capability will contribute to the accelerator being classified in group 1.

Moreover, analyzing the structure matrix enhances interpretation of our models. The structure matrix shows the canonical correlations between the discriminant function and each one of the predicting variables. We observed that all the variables are loaded on the discriminant function which means that all variables are associated with accelerator performance. Regardless some variables were more successful as predictors. These variables are: in model $\left(\mathrm{S}_{\mathrm{i}}\right)$, "Teach entrepreneurs about the identification and monitoring of metrics and KPIs" $\left(\mathrm{S}_{4}\right)$, "Help entrepreneurs to define and track their metrics and KPIs" $\left(\mathrm{S}_{5}\right)$ and "Use of a methodology that help them and guide entrepreneurs during the process" $\left(\mathrm{S}_{3}\right)$; in model $\left(\mathrm{A}_{\mathrm{i}}\right)$, "Entrepreneurs have individual sessions with mentors in their program" $\left(\mathrm{A}_{6}\right)$ and "Review the results and metrics with each entrepreneur to help them interpret and make decisions" $\left(\mathrm{A}_{7}\right)$ and finally, in model $\left(\mathrm{S}_{\mathrm{i}}+\mathrm{A}_{\mathrm{i}}+\mathrm{INT}_{\mathrm{i}}+\mathrm{INN}_{\mathrm{i}}\right)$, those related to sensing the market capability and absorption capability.

\begin{tabular}{|c|c|c|}
\hline Variable & SCC & Structure matrix \\
\hline \multicolumn{3}{|l|}{ Sensing the market variables $\left(S_{i}\right)$} \\
\hline $\begin{array}{l}\mathrm{S}_{1} \text {, Mentors of the accelerator help / guide the entrepreneurs } \\
\text { in the development and testing of business hypotheses. }\end{array}$ & 0.399 & 0.268 \\
\hline $\begin{array}{l}\mathrm{S}_{2} \text {, Inculcate entrepreneurs the importance of gaining real } \\
\text { knowledge of their target market / customers }\end{array}$ & -0.543 & 0.093 \\
\hline $\begin{array}{l}\mathrm{S}_{3} \text {, Use of a methodology that help them and guide } \\
\text { entrepreneurs during the process }\end{array}$ & 0.503 & 0.313 \\
\hline $\begin{array}{l}\mathrm{S}_{4} \text {, Teach entrepreneurs about the identification and } \\
\text { monitoring of metrics and KPIs }\end{array}$ & 0.85 & 0.75 \\
\hline $\begin{array}{l}\mathrm{S}_{5} \text {, Help entrepreneurs to define and track their metrics and } \\
\text { KPIs. }\end{array}$ & 0.222 & 0.672 \\
\hline \multicolumn{3}{|l|}{ Absorption variables $\left(\mathbf{A}_{\mathbf{i}}\right)$} \\
\hline $\begin{array}{l}\mathrm{A}_{1} \text {, Organize workshops to meet the needs / abilities of } \\
\text { entrepreneurs }\end{array}$ & 1.012 & -0.02 \\
\hline $\begin{array}{lllll}\mathrm{A}_{2}, \quad \text { Organize } & \text { sessions } & \text { between } & \text { entrepreneurs } & \text { and } \\
\text { stakeholders } & & & & \end{array}$ & -0.063 & -0.057 \\
\hline$A_{3}$, Facilitate the contact of the entrepreneurs with experts & 0.051 & 0.131 \\
\hline $\begin{array}{l}\mathrm{A}_{4} \text {, Facilitate the contact of the entrepreneurs with potential } \\
\text { clients and / or specific communities }\end{array}$ & -0.486 & -0.17 \\
\hline $\mathrm{A}_{5}$, Entrepreneurs have individual sessions with experts & 0.705 & 0.167 \\
\hline $\begin{array}{l}\mathrm{A}_{6} \text {, Entrepreneurs have individual sessions with mentors in } \\
\text { their program. }\end{array}$ & -1.529 & -0.275 \\
\hline $\begin{array}{l}\mathrm{A}_{7} \text {, Review the results and metrics with each entrepreneur to } \\
\text { help them interpret and make decisions. }\end{array}$ & 1.238 & 0.314 \\
\hline \multicolumn{3}{|l|}{ All groups $\left(\mathrm{S}_{\mathrm{i}}+\mathrm{A}_{\mathrm{i}}+\mathrm{INT}_{\mathrm{i}}+\mathrm{INN}_{\mathrm{i}}\right)$} \\
\hline Sensing the market variables $\left(\mathrm{S}_{\mathrm{i}}\right)$ & 1.43 & 0.716 \\
\hline Absorption variables $\left(\mathrm{A}_{\mathrm{i}}\right)$ & -0.365 & 0.174 \\
\hline Integration variables $\left(\mathrm{INT}_{\mathrm{i}}\right)$ & -0.801 & 0.05 \\
\hline Innovation variables $\left(\mathrm{INN}_{\mathrm{i}}\right)$ & -0.083 & -0.011 \\
\hline
\end{tabular}

Table 2. Standardized canonical coefficients (SCC) and Structure matrix

\begin{tabular}{|l|r|r|}
\cline { 2 - 3 } \multicolumn{1}{c|}{} & \multicolumn{1}{c|}{$\mathbf{1}$} & \multicolumn{1}{c|}{$\mathbf{2}$} \\
\hline Sensing the market variables $\left(\mathbf{S}_{\mathbf{i}}\right)$ & 0.552 & -1.656 \\
\hline Absorption variables $\left(\mathbf{A}_{\mathbf{i}}\right)$ & 0.747 & -2.242 \\
\hline All group & 0.54 & -1.62 \\
\hline
\end{tabular}

Table 3. Functions at group centroids 


\section{Discussion and conclusion}

This paper examines business accelerator programs as engines that power the development of dynamic capabilities within startups. The present paper has analyzed the generation of dynamic capabilities within a sample of Spanish business accelerators and assessed the effect of these capabilities on their performance, which has been measured in terms of percentage of firms financed.

Our findings show that business accelerator routines have an influence on the generation of their startups' dynamic capabilities and on their performance. However, not all dynamic capabilities influence equally, confirming the need to separate between their dimensions to analyze their effects (Helfat \& Winter, 2011; Hernández-Linares et al., 2018). We hypothesized that the different routines embedded in business acceleration programs influence the generation of the following capabilities: Sensing the market, absorption, integration, and innovation. The startups' performance overall is also influenced.

First, empirical results show that in the case of sensing the market, the variables that stood out as being considerably more important than others are those related to the use of a methodology for guiding entrepreneurial action and teaching them to use the tools and techniques to follow and also assisting them during the definition of business objectives (KPIs) and tracking their status (metrics). We found that a higher frequency in developing those routines by accelerators would lead to worsen performance in terms of startup financing. In our results, business accelerators that put more effort in helping startups to evaluate the viability of their business and resolve the uncertainty of their contexts, both market and technological one, contribute more to developing their sensing the market capability but, at the same time, show a diminished likelihood of receiving additional funding. These results support existing work in the literature (e.g. Amezcua, Grimes, Bradley \& Wiklund, 2013; Bone, Gonzalez-Uribe, Haley \& Lahr, 2019; Schwartz, 2013; Yu, 2018) that suggests that business accelerators by favoring discovery-validating driven approaches among their startups are helping them to undertake their first steps analyzing the market and technology. This helps them to uncover uncertainty around their feasibility which results killing bad business ideas sooner than they otherwise would. This leads to a higher rate failure.

In business accelerators that pay attention to helping their startups to understand how effective they are at achieving their business objectives (KPIs) and track their status (metrics), it would seem reasonable that the feasibility of their business opportunities are resolved much faster, enhancing their sensing the market capability but at the same time allowing them to make exit decisions sooner rather than later. Also, another potential answer could be the inability of startups to have a proper balance between the demands of the imposed methodology and their existing business requirement. This is due to the lack of available resources to manage both processes efficiently.

The results of the absorption capability model show that the mentorship variable is the strongest predictor to separate between groups. Our findings indicate that intensive mentorship facilitates and promotes startups' performance. This result corroborates prior research indicating the key role of mentors in acceleration programs (Cohen et al., 2019; Qian, Mulas \& Lerner, 2018) and their positive impact in terms of new knowledge acquisition (Battistella et al., 2017; Gonzalez-Uribe \& Leatherbee, 2016; Hallen, Cohen \& Bingham, 2016; PoloGarcía-Ochoa, 2020; Qian et al., 2018; Seet, Jones, Oppelaar \& Corral de Zubielqui, 2018; Wise \& Valliere, 2014). In line with other studies, our results show how learning from mentors enables dynamic capabilities generation resulting in better performance in terms of probability of getting funded (Ambrosini \& Bowman, 2009; Hernández-Linares et al., 2018; Li \& Liu, 2014; Tsai, 2001; Qian et al., 2018). Besides the challenge of transferring tacit knowledge in new ventures, (Cohen, 2013; Von Hippel, 1988),mentors appear to provide the needed assistance and access to the knowledge required for building absorptive capacity. All in all, the more mentorship a firm has, the stronger the absorption capability that will be developed and the more likelihood of receiving additional funding.

Also, access to networking opportunities shows a moderately strong contribution to startups success. This supports previous findings in which accelerated startups benefit from the access to networks (customers, stakeholders, etc.)(Amezcua et al., 2013; Hallen et al., 2016; Roberts et al., 2016). Similar to mentors, 
introductions to customers and stakeholders help startups to gain access to the right knowledge. In fact, in line with other studies (e. g, Macpherson et al., 2004), building an effective business network may allow knowledge transfer and knowledge creation. Thus, the more that business accelerators facilitate relationships between potential customers and stakeholders, the more they enable knowledge to be transferred, creating knowledge linkages that facilitate the generation of the absorption capability (Debrulle, 2012; Honig \& Davidsson, 2000). These results demonstrate the importance of developing both strong ties, close relationships (mentors) and weak ties, distant relationships (e.g. access to customers and stakeholders) to enhance startups' absorption capability (Hansen, 1999; Todorova \& Durisin, 2007). In contrast to Zahra and George (2002), who argue that only strong ties may have a positive impact on absorptive capacity. These findings suggest that intense interactions with mentors, customers and stakeholders are excellent routines to gather external information and introduce it into the start-up, understand information more fully in the assimilation process, and also, to help them point out where the knowledge application might be most profitable. Accelerators which enable founders to have more frequent access to mentors, potential clients and stakeholders are enhancing their absorption capability as well as their probabilities to get financed. By contrary, in our study, other learning mechanisms like consultation with experts and seminars on management topics (legal, marketing, accounting) have a negative influence. These findings are consistent with results from Qian et al. (2018) who found that practical operational experience may be more important than technical knowledge. Since experts are not founders but rather professors or corporate professionals and their interactions are focused on formal education, they mainly assist startups in the development of explicit knowledge (Honig \& Davidsson, 2000). As such, it could be that startups' absorptive capacity benefits little from that type of knowledge compared to the one based on experience (e.g. mentors) (Debrulle, 2012; Thorpe, Holt, Macpherson \& Pittaway, 2005).

With respect to "review of results routines to help them interpret and make decisions", our results indicated that an active participation in this process by accelerator staff has a negative effect on startups' performance. Although this result could be surprising, a potential answer could be that routines that imply an intense direct intervention in the startups' development process by someone outside them could hinder the correct valuing and exploitation of knowledge (Todorova \& Durisin, 2007).

We did not find statistical relevance for integration and innovation models. However, when we analyze all variables together (model 3), their effects emerge which may be that only when they are accompanied by other DC dimensions, they reach enough significance. Summarizing our findings when taking together the four DC dimensions, we distinguished a moderate strong contribution and positive effect of absorption and integration capabilities. Our results on this matter prove to be consistent with those of earlier research on the positive contribution of integration capability on ventures performance (Helfat \& Raubitschek, 2018; Hernández-Linares et al., 2018; Tseng \& Lee, 2014).

This finding indicates that startups integration capability benefits from intense interaction with external parties (mentors and business accelerators staff) aimed to posit a regular pace on delivery and outcomes. These routines enhance internal knowledge exchange and influence communication processes within startups (Carnahan, Agarwal \& Campbell, 2017; Götz et al., 2020; Helfat \& Raubitschek, 2018). As such, the more business accelerators deploy these routines, the more startups are able to stimulate knowledge integration, enabling startups to make the necessary realignment and readjustment, in addition to facilitating collective understanding. Regarding innovation capability, our results suggest a light contribution of this DC to startups performance. This finding enables us to take first steps in addressing how startups enhance their innovation capability within business accelerators, but further investigation is needed.

This study has a number of limitations that must be taken into account when interpreting our findings. These limitations also represent directions for new opportunities and future research. First, because data was gathered from a single country, and based on a survey, it is subject to biases and errors inherent in self-reported datasets and also its cross-sectional design limits generalization and restricts our ability to infer causal relationships from results. Second, this study pioneers academic research on accelerators and dynamic capabilities. Thus, although our measurement models show acceptable significance for most of them, there is still a long way to establish 
well-developed measures of such complex constructs. Clearly, more research is necessary to better describe, and measure business accelerators routines linked to startups' dynamic capabilities.

In conclusion, this study provides some insight about which business accelerator mechanisms are potentially more important in determining how accelerated startups can increase their financing probabilities. We note that this is a preliminary attempt to help in the untangling of the dynamic capability and the business incubation black box (Hackett \& Dilts, 2008; Pavlou \& El Sawy, 2011). Future studies could employ a longitudinal design, as well as include a wider range of survey participants (not just the business accelerator director) such as accelerated startups or mentors to avoid any distorted self-reports and socially desirable answers. Also, further examination and analysis can be made by deepening the search for business incubation routines that generate startups' dynamic capabilities. Furthermore, future work might include not only ultimate outcomes (e.g. follow up funding) but additional intermediate outcomes (e.g. recruiting, strategic planning, etc.) to deepen the understanding of the effect of business accelerators support (Bone et al., 2019).

\section{Declaration of Conflicting Interests}

The authors declared no potential conflicts of interest with respect to the research, authorship, and/or publication of this article.

\section{Funding}

The authors received no financial support for the research, authorship, and/or publication of this article.

\section{References}

Akman, G., \& Yilmaz, C. (2008). Innovative Capability, Innovation Strategy and Market Orientation: An Empirical Analysis in Turkish Software Industry. International Journal of Innovation Management, 12(01), 69-111. https://doi.org/10.1142/S1363919608001923

Ambrosini, V., \& Bowman, C. (2009). What are dynamic capabilities and are they a useful construct in strategic management?. International Journal of Management Reviews, 11(1), 29-49. https://doi.org/10.1111/j.14682370.2008.00251.x

Amezcua, A.S., Grimes, M.G., Bradley, S.W., \& Wiklund, J. (2013). Organizational sponsorship and founding environments: A contingency view on the survival of business-incubated firms, 1994-2007. Academy of Management Journal, 56(6), 1628-1654. https://doi.org/10.5465/amj.2011.0652

Ardichvili, A., Cardozo, R., \& Ray, S. (2003). A theory of entrepreneurial opportunity identification and development. Journal of Business Venturing, 18, 105-123. https://doi.org/10.1007/s00128-017-2113-7

Atomico (2019). State of European Tech. Available at: https://2019.stateofeuropeantech.com/

Barrehag, L., Fornell, A., Larsson, G., Mårdström, V., Westergård, V., \& Wrackefeldt, S. (2012). Accelerating Success: A Study of Seed Accelerators and Their Defining Characteristics. Chalmers University of Technology.

Battistella, C., De Toni, A.F., \& Pessot, E. (2017). Open accelerators for start-ups success: a case study. European Journal of Innovation Management, 20(1), 80-111. https://doi.org/10.1108/EJIM-10-2015-0113

Bastanchury-Lopez, M.T., De Pablos Heredero, C., García-Martínez, R., \& Martín-Romo Romero, S. (2019). Review of the measurement of dynamic capacities: A proposal of indicators for the sheep industry. Revision de la medición de capacidades dinámicas: Una. Cienc Tecnol Agropecuaria, Mosquera, 20(2), 1-15.

Blanco Callejo, M., \& De Pablos Heredero, C. (2019). Co-innovation at Mercadona: A radically different and unique innovation model in the retail sector. Journal of Business \& Retail Management Research, 13(04), 326-341. https://doi.org/10.24052/jbrmr/v13is04/art-30

Blank, S., \& Dorf, B. (2012). The Startup Owner's Manual: The Step-by-Step Guide for Building a Great Company. California: K. \& S. Ranch, Ed. 
Bone, J., Gonzalez-Uribe, J., Haley, C., \& Lahr, H. (2019). The impact of business accelerators and incubators in the UK. United Kingdom - Department of Business, Energy \& Industrial Strategy, 125. Retrieved from: https://www.gov.uk/government/organisations/department-for-business-energy-and-industrial-strategy

Brown, R., Mawson, S., Lee, N., \& Peterson, L. (2019). Start-up factories, transnational entrepreneurs and entrepreneurial ecosystems: Unpacking the lure of start-up accelerator programmes. European Planning Studies, 27(5), 885-904. https://doi.org/10.1080/09654313.2019.1588858

Carnahan, S., Agarwal, R., \& Campbell, B. (2017). Battle on the Wrong Field? Entrant Type, Dominant Designs, and Technology Exit. Strategic Management Journal, 38(July), 2579-2598. https://doi.org/10.1002/smj.2669

Chen, Y.S., Lin, M.J.J., \& Chang, C.H. (2009). The positive effects of relationship learning and absorptive capacity on innovation performance and competitive advantage in industrial markets. Industrial Marketing Management, 38(2), 152-158. https://doi.org/10.1016/j.indmarman.2008.12.003

Clarysse, B., Wright, M., \& van Hove, J. (2015). A look inside Building Businesses. London: Nesta.

Cohen, S., Fehder, D.C., Hochberg, Y.V., \& Murray, F. (2019). The design of startup accelerators. Research Policy, 48(7), 1781-1797. https://doi.org/10.1016/j.respol.2019.04.003

Cohen, S., \& Hochberg, Y.V. (2014). Accelerating Startups: The Seed Accelerator Phenomenon. SSRN Electronic Journal, Available at SSRN 2418000. https://doi.org/10.2139/ssrn.2418000

Cohen, S.L. (2013). How To Accelerate Learning: Entrepreneurial Ventures Participating in Accelerator Programs. Doctoral Dissertation, 1, 1-140. https://doi.org/10.5465/ambpp.2013.14803abstract

Cohen, W.M., \& Levinthal, D.A. (1990). Absorptive Capactiy: A new perspective on learning and innovation. Administrative Science Quarterly, 35(1), 128-152. https://doi.org/10.2307/2393553

Corner, P.D., \& Wu, S. (2012). Dynamic capability emergence in the venture creation process. International Small Business Journal, 30(2), 138-160. https://doi.org/10.1177/0266242611431092

Dana, L.P., \& Wright, R.W. (2008). International entrepreneurship: Research priorities for the future. International Journal of Globalisation and Small Business, 3(1), 90. https://doi.org/10.1504/IJGSB.2009.021572

Debrulle, J. (2012). Start-up absorptive capacity: Does the owner's human and social capital matter? (No. 30). Katholieke Universiteit Leuven. https://doi.org/10.2139/ssrn.2285777

Deeds, D.L., DeCarolis, D., \& Coombs, J. (1999). Dynamic capabilities and new product development in high technology ventures: An empirical analysis of new biotechnology firms. Journal of Business Venturing, 15(3), 211-229. https:// doi.org/10.1016/S0883-9026(98)00013-5

De Pablos Heredero, C., García, A., \& Martín-Romo, S. (2019). Revision of dynamic capabilities measurement: A proposal of indicators for the sheep industry. Corpoica Ciencia y Tecnología Agropecuaria, 20(2), 371-386.

De Pablos Heredero, C., Fern, G., \& Blanco-Callejo, M. (2017). Supplier Qualification Sub-Process from a Sustained Perspective: Generation of Dynamic Capabilities. Sustainability, 6, 341-377. https://doi.org/10.3390/su9050730

De-Pablos-Heredero, C., \& López Berzosa, D. (2012) La importancia de los mecanismos de coordinación organizativa en la excelencia del sistema español de trasplantes. Intangible. Capital, 8, 17-42.

Eisenhardt, K.M., \& Martin, J.A. (2000). Dynamic Capabilities: What Are They?. Strategic Management Journal, 21, 1105-1121. https://doi.org/10.1002/1097-0266(200010/11)21:10/11<1105::AID-SMJ133>3.0.CO;2-E

Fowle, M., \& Tyne, N. (2017). Critical Success Factors for Business Accelerators: A Theoretical Context. In British Academy of Management 2017. Warwick Business School.

Garcés, C., \& Mkheidze, T. (2018). Start-ups' Motives, Approaches, and Opportunities for Using Open Innovation. Sweden: Lund University.

Gartner, W.B. (1990). What are we talking about when we talk about entrepreneurship?. Journal of Business Venturing, 5(1), 15-28. https://doi.org/10.1016/0883-9026(90)90023-M 
Gonthier, J., \& Chirita, G.M. (2019). The role of corporate incubators as invigorators of innovation capabilities in parent companies. Journal of Innovation and Entrepreneurship, 8(1), 2-21. https://doi.org/10.1186/s13731-0190104-0

Gonzalez-Uribe, J., \& Leatherbee, M. (2016). Business Accelerators and New-Venture Performance: Evidence from Start-Up Chile. The Review of Financial Studies, 31(4), 1566-1603. https://doi.org/10.1093/rfs/hhx103

Goswami, K., Mitchell, J.R., \& Bhagavatula, S. (2018). Accelerator expertise: Understanding the intermediary role of accelerators in the development of the Bangalore entrepreneurial ecosystem. Strategic Entrepreneurship Journal, 12(1), 117-150. https://doi.org/10.1002/sej.1281

Götz, F., Hamann, C., Meckl, R., Buck, C., Oesterle, S., \& Eymann, T. (2020). Dynamic Capabilities as the Key Approach to Investigate Digital Ecosystems. In WI2020 Zentrale Tracks (pp. 1396-1411). https://doi.org/10.30844/wi_2020_m5-goetz

Hackett, S.M., \& Dilts, D.M. (2004). A Real Options-Driven Theory of Business Incubation. Journal of Tecbnology Transfer, 29, 41-54. https://doi.org/10.1023/B

Hackett, S.M., \& Dilts, D.M. (2008). Inside the black box of business incubation: Study B - Scale assessment, model refinement, and incubation outcomes. Journal of Technology Transfer, 33(5), 439-471. https://doi.org/10.1007/s10961-007-9056-9

Hallen, B.L., Cohen, S., \& Bingham, C. (2016). Do Accelerators Accelerate? If So, How? The Impact of Intensive Learning from Others on New Venture Development. SSRN Electronic Journal, (1). 3-12. https://doi.org/10.2139/ssrn.2719810

Hallen, B.L., Cohen, S.L., Bingham, C.B., Durando, G., Glasscock, W., Ferguson, D., et al. (2019). Do Accelerators Work? If So, How?. Organization Science, 31(2), 378-414. Retrieved from: $\underline{\text { https: //ssrn.com/abstract }=2719810}$

Hansen, M.T. (1999). The Search-Transfer Problem: The Role of Weak Ties in Sharing Knowledge across Organization Subunits. Administrative Science Quarterly, 44(1), 82-111. Retrieved from: http://www.jstor.org/stable/2667032

Hausberg, J.P., \& Korreck, S. (2018). Business incubators and accelerators: a co-citation analysis-based, systematic literature review. Journal of Technology Transfer, 45, 1-26. https://doi.org/10.1007/s10961-018-9651-y

Helfat, C.E., \& Raubitschek, R.S. (2018). Dynamic and integrative capabilities for profiting from innovation in digital platform-based ecosystems. Research Policy, 47(8), 1391-1399. https://doi.org/10.1016/j.respol.2018.01.019

Helfat, C.E., \& Winter, S.G. (2011). Untangling Dynamic and Operational Capabilities: Strategy for the (N)everChanging World. Strategic Management Journal,32, 1243-1250. https://doi.org/10.1002/smj.955

Hernández-Linares, R., Kellermanns, F.W., \& López-Fernández, C. (2018). Dynamic Capabilities and SME Performance: The Moderating Effect of Market Orientation. Journal of Small Business Management, 00, 1-26. https://doi.org/10.1111/jsbm.12474

Hidalgo-Peñate, A., Padrón-Robaina, V., \& Nieves, J. (2019). Knowledge as a driver of dynamic capabilities and learning outcomes. Journal of Hospitality, Leisure, Sport and Tourism Education, 24(March 2018), 143-154. https://doi.org/10.1016/j.jhlste.2019.02.004

Hoffman, D.L., \& Radojevich-Kelley, N. (2012). Analysis of Accelerator Companies: An Exploratory Case Study of Their Programs, Processes, and Early Results. Small Business Institute Journal, 8(2), 54-70.

Honig, B., \& Davidsson, P. (2000). the Role of Social and Human Capital Among Nascent Entrepreneurs. Academy of Management Proceedings, 2000(1), B1-B6. https://doi.org/10.5465/apbpp.2000.5438611

Jiao, H., Alon, I., \& Cui, Y. (2011). Environmental dynamism, innovation, and dynamic capabilities: The case of China. Journal of Enterprising Communities, 5(2), 131-144. https://doi.org/10.1108/17506201111131550 
Jones, O. Macpherso, A. Jayawarna, D. (2014). Learning to Grow: Dynamic Capabilities in New Technology-based Firms. Paper Presented at the British Academy of Management (BAM) Conference, Aston University, Birmingham, 44(1), 1-5. https://doi.org/10.1007/s13398-014-0173-7.2

Jones, O., Macpherson, A., \& Jayawarna, D. (2013). Resourcing the Start-Up Business: Creating Dynamic Entrepreneurial Learning Capabilities. Taylor \& Francis. Retrieved from: https://books.google.es/books?id=OiliAQAAQBAJ https://doi.org/10.4324/9780203104569

Juntunen, M. (2017). Business Model Change As a Dynamic Capability. Retrieved from: http://jultika.oulu.fi/files/isbn9789526216621.pdf

Keh, H.T., Nguyen, TT. M., \& Ng, H.P. (2007). The effects of entrepreneurial orientation and marketing information on the performance of SMEs. Journal of Business Venturing, 22(4), 592-611. https://doi.org/10.1016/j.jbusvent.2006.05.003

Kohler, T. (2016). Corporate accelerators: Building bridges between corporations and startups. Business Horizons, 59(3), 347-357. https://doi.org/10.1016/j.bushor.2016.01.008

Konsti-Laakso, S., Pihkala, T., \& Kraus, S. (2012). Facilitating SME innovation capability through business networking. Creativity and Innovation Management, 21(1), 93-105. https://doi.org/10.1111/j.1467-8691.2011.00623.x

Lane, P.J., \& Lubatkin, M. (1998). Relative absorptive capacity and interorganizational learning. Strategic Management Journal, 19(5), 461-477. https://doi.org/10.1002/(SICI)1097-0266(199805)19:5<461::AIDSMJ953>3.3.CO;2-C

Leih, S., Linden, G., \& Teece, D.J. (2014). Business Model Innovation and Organizational Design: a Dynamic Capabilities Perspective (pp. 14-22). Business Model Innovation, Oxford University Press. https://doi.org/10.1093/acprof

Li, D.Y., \& Liu, J. (2014). Dynamic capabilities, environmental dynamism, and competitive advantage: Evidence from China. Journal of Business Research, 67(1), 2793-2799. https://doi.org/10.1016/j.jbusres.2012.08.007

Liao, J., Kickul, J.R., \& Ma, H. (2009). Innovation: An Empirical Examination of Internet Firms. Journal of Small Business Management, 47(3), 263-286.

Lumpkin, G.T., \& Jerome A.K. (2007). Entrepreneurial Strategic Process. Elsevier, 10, 1-7. https://doi.org/10.1017/CBO9781107415324.004

Macpherson, A., Jones, O., \& Zhang, M. (2004). Evolution or revolution Dynamic capabilities in a knowledgedependent firm. R\&D Management, 34(2), 161-177.

Madsen, E.L. (2010). A Dynamic Capability Framework- Generic dimensions of Dynamic Capabilities and Their Relationship to Entrepreneurship. In S. Wall, C. Zimmermann, R. Klingebiel, \& D. Lange (Eds.), Strategic Reconfigurations: Building Dynamic Capabilities in Rapid-Innovation-Based Industries. Chaltenham: Edward Elgar.

Martínez García, I., Padilla Carmona, M.T., \& Suárez Ortega, M. (2019). Aplicación de la metodología Delphi a la identificación de factores de éxito en el emprendimiento. Revista de Investigación Educativa, 37(1), 129-146. https://doi.org/10.6018/rie.37.1.320911

Miller, P., \& Bound, K. (2011). The Startup Factories. London: Nesta. https://doi.org/10.1017/CBO9781107415324.004

Mobile World Congress (2019). Startup Ecosystem Overview 2019.

Monferrer, D., Blesa, A., \& Ripollés, M. (2013). Orientación al mercado de la red y capacidades dinámicas de absorción e innovación como determinantes del resultado internacional de las nuevas empresas internacionales. Revista Española de Investigación de Marketing ESIC, 17(2), 29-52. https://doi.org/10.1016/S11381442(14)60023-1

Newbert, S.L. (2005). New firm formation: A dynamic capability perspective. Journal of Small Business Management, 43(1), 55-77. https://doi.org/10.1111/j.1540-627X.2004.00125.x 
Pandza, K., \& Holt, R. (2007). Absorptive and transformative capacities in nanotechnology innovation systems. Journal of Engineering and Technology Management - JET-M, 24(4), 347-365.

https://doi.org/10.1016/j.jengtecman.2007.09.007

Pauwels, C., Clarysse, B., Wright, M., \& Van Hove, J. (2016). Understanding a new generation incubation model: The accelerator. Technovation, 50/51, 13-24. https://doi.org/10.1016/j.technovation.2015.09.003

Pavlou, P.A., \& El Sawy, O.A. (2011). Understanding the Elusive 'Black Box' of Dynamic Capabilities. Decision Sciences Journal, 42(1), 239-273. https://doi.org/10.1111/j.1540-5915.2010.00287.x

Polo García-Ochoa, C. (2020). How business accelerators foster startups' dynamic capabilities: A case study. ESIC MARKET Economic and Business Journal, 51(1), 19-44. https://doi.org/10.7200/esicm.165.0511.1

Prajogo, D.I., \& Ahmed, P.K. (2006). Relationships between innovation stimulus, innovation capacity, and innovation performance. $R$ and D Management, 36(5), 499-515. https://doi.org/10.1111/j.1467-9310.2006.00450.x

Qian, K., Mulas, V., \& Lerner, M. (2018). Supporting Entrepreneurs at the Local Level: The Effect of Accelerators and Mentors on Early-Stage Firms. Retrieved from: www.worldbank.org

Rao, R.S., Chandy, R.K., \& Prabhu, J.C. (2008). The Fruits of Legitimacy: Why Some New Ventures Gain More from Innovation Than Others. Journal of Marketing, 72(4), 58-75. https://doi.org/10.1509/jmkg.72.4.58

Ries, E. (2013). El método Lean Startup: Cómo crear empresas de éxito utilizando la innovación continua. Barcelona: Grupo Planeta. https://doi.org/23

Roberts, P.W., Lall, S., Baird, R., Eastman, E., Davidson, A., \& Jacobson, A. (2016). What's Working in Startup Acceleration - Insights from Fifteen Village Capital Programs. Insights from Fifteen Village Capital Programs, (March), 43.

Roseno, A., Enkel, E., \& Mezger, F. (2013). Distinctive dynamic capabilities for new business creation: Sensing, seizing, scaling and separating. International Journal of Technology Marketing, 8(2), 197-234. https://doi.org/10.1504/IJTMKT.2013.054072

Sapienza, H.J., Autio, E., George, G., \& Zahra, S.A. (2006). A capabilities perspective on the effects of early internationalization on firm survival and growth. Academy of Management Review, 31(4), 914-933. https://doi.org/10.5465/AMR.2006.22527465

Saunila, M., \& Ukko, J. (2014). Intangible aspects of innovation capability in SMEs: Impacts of size and industry. Journal of Engineering and Technology Management - JET-M, 33, 32-46. https://doi.org/10.1016/j.jengtecman.2014.02.002

Schwartz, M. (2013). A control group study of incubators' impact to promote firm survival. Journal of Technology Transfer, 38(3), 302-331. https://doi.org/10.1007/s10961-012-9254-y

Seet, P.S., Jones, J., Oppelaar, L., \& Corral de Zubielqui, G. (2018). Beyond 'know-what' and 'know-how' to 'know-who': enhancing human capital with social capital in an Australian start-up accelerator. Asia Pacific Business Review, 24(2), 233-260. https://doi.org/10.1080/13602381.2018.1431250

Shankar, R.K., \& Shepherd, D.A. (2019). Accelerating strategic fit or venture emergence: Different paths adopted by corporate accelerators. Journal of Business Venturing, 34(5), 105886.

https://doi.org/10.1016/j.jbusvent.2018.06.004

Skarzynski, P., \& Gibson, R. (2008). Innovation to the core - a blueprint for transforming the way your company innovates. Boston, Massachusetts: Harvard Business Press. https://doi.org/10.1007/s10689-011-9490-6

Smith, S.W., \& Hannigan, T.J. (2015). Swinging for the Fences: How Do Top Accelerators Impact the Trajectories of New Ventures? DRUID Conference, 2015, 29.

Sommer, S.C., Loch, C.H., \& Dong, J. (2008). Managing Complexity and Unforeseeable Uncertainty in Startup Companies: An Empirical Study. Organization Science, 20(1), 118-133. https://doi.org/10.1287/orsc.1080.0369 
Song, M., Podoynitsyna, K., Van Der Bij, H., \& Halman, J.I.M. (2008). Success factors in new ventures: A metaanalysis. Journal of Product Innovation Management, 25, 7-27. https://doi.org/10.1111/j.1540-5885.2007.00280.x

Stross, R. (2012). The launch pad: Inside Y Combinator, Silicon Valley's most exclusive school for startups. New York: Portfolio/Penguin.

Teece, D.J. (2007). Explicating dynamic capabilities: the nature andmicrofoundations of (sustainable) enterprise performance. Strategic Management Journal, 51(2), 315-334. https://doi.org/10.1002/smj

Teece, D.J. (2012). Dynamic Capabilities: Routines versus Entrepreneurial Action. Journal of Management Studies, 49(8), 1395-1401. https://doi.org/10.1111/j.1467-6486.2012.01080.x

Teece, D., Pisano, G., \& Shuen, A. (1997). Dynamic capabilities and strategic management. Strategic Management Journal, 18(7), 509-533. https://doi.org/10.1002/(SICI)1097-0266(199708)18:7<509::AID-SMJ882>3.0.CO;2-Z

Telussa, J., Stam, E., \& Gibcus, P. (2006). Entrepreneurship, Dynamic Capabilities and New Firm Growth. Scientific Analysis of Entrepreneurship and SMEs. Retrieved from: http://ideas.repec.org/p/eim/papers/h200623.html

Thorpe, R., Holt, R., Macpherson, A., \& Pittaway, L. (2005). Using knowledge within small and medium-sized firms: A systematic review of the evidence. International Journal of Management Reviews, 7(4), 257-281. https://doi.org/10.1111/j.1468-2370.2005.00116.x

Todorova, G., \& Durisin, B. (2007). Absorptive Capacity: Valuing a Reconceptualization. Academy of Management Review, 32(3), 774-786.

Torrado-Fonseca, M., \& Reguant-Álvarez, M. (2016). El mértodo Delphi. REIRE. Revista d’Innovació i Recerca En Educació, 9(1), 0-2. https://doi.org/10.1344/reire2016.9.1916

Trimi, S., \& Berbegal-Mirabent, J. (2012). Business model innovation in entrepreneurship. International Entrepreneurship and Management Journal, 8(4), 449-465. https://doi.org/10.1007/s11365-012-0234-3

Tsai, W. (2001). Knowledge Transfer in Intraorganizational Networks: Effects of Network Position and Absorptive Capacity on Business Unit Innovation and Performance Author(s). Wenpin Tsai Source. The Academy of Management Journal, 44(5)(Oct., 2001), Academic of Management Journal, 44(5), 996-1004.

Tseng, S.M., \& Lee, P.S. (2014). The effect of knowledge management capability and dynamic capability on organizational performance. Journal of Enterprise Information Management, 27(2), 158-179. https://doi.org/10.1108/JEIM-05-2012-0025

Varela-Ruiz, M., \& Díaz-Bravo, L. (2012). Descripción y usos de la técnica Delphi. Metodología De Investigación En Educación Médica, 1(2), 90-95. Retrieved from: http://www.scielo.org.mx/pdf/iem/v1n2/v1n2a7.pdf

Von Hippel, E. (1988). The Sources of Innovation. New York: Oxford University Press (Oxford Uni, Vol. 3). New York. Retrieved from: http://repositorio.unan.edu.ni/2986/1/5624.pdf

Wan, D., Ong, C.H., \& Lee, F. (2005). Determinants of firm innovation in Singapore. Technovation, 25(3), 261-268. https://doi.org/10.1016/S0166-4972(03)00096-8

Wang, C.L., \& Ahmed, P.K. (2004). The Development and Validation of the Organisational Innovativeness Construct Using Confirmatory Factor Analysis. Journal? Book?

Wang, C.L., \& Ahmed, P.K. (2007). Dynamic Capabilities: A Review and Research Agenda. The International Journal of Management Reviews, 9, 31-51. https://doi.org/10.1111/j.1468-2370.2007.00201.x

Wernerfelt, B. (1984). A resource-based view of the firm. Strategic Management Journal, 5(2), 71-180. https://doi.org/10.1002/smj.4250050207

West, G.P., \& Noel, T.W. (2009). The impact of knowledge resources on new venture performance. Journal of Small Business Management, 47(1), 1-22.

Winter, S.G. (2003). Understanding dynamic capabilities. Strategic Management Journal, 24(10 Spec. Iss.), 991-995. https://doi.org/10.1002/smj.318 
Wise, S., \& Valliere, D. (2014). The impact on management experience on the performance of start-ups within accelerators. The Journal of Private Equity, 18(1), 9-19.

Wójcik, P. (2015). Exploring Links Between Dynamic Capabilities Perspective and Resource-Based View: A Literature Overview. International Journal of Management and Economics, 45(1), 83-107. https://doi.org/10.1515/ijme-2015-0017

Wright, M., \& Drori, I. (Eds.). (2018). Accelerators: Successful Venture Creation and Growth. Cheltenham, UK: Edward Elgar Publishing.

Wu, L.Y. (2007). Entrepreneurial resources, dynamic capabilities and start-up performance of Taiwan's high-tech firms. Journal of Business Research, 60(5), 549-555. https://doi.org/10.1016/j.jbusres.2007.01.00

Yang, S., Kher, R., \& Lyons, T.S. (2018). Where do Accelerators fit in the venture creation pipeline? Different Values Brought by different types of accelerators. Entrepreneurship Research Journal, 8(4), 1-27. https://doi.org/https://doi.org/10.1515/erj-2017-0140

Y Combinator (2020) Retrieved 15 june 2020 from: https://www.ycombinator.com

Yu, S. (2018). How Do Accelerators Impact High-Technology Ventures?. Management Science, R\&R, 66(2) 503-1004. https://doi.org/10.2139/ssrn.2503510

Yusubova, A., \& Clarysse, B. (2016). Success factors of business accelerators in three European cities- Paris, London, Berlin. In Technology entrepreneurship and business incubation: Theory, practice, lessons learned (pp. 35-56). https://doi.org/10.1109/msr.2009.5069473

Zahra, A.S., \& George, G. (2002). Absorptive Capacity: A review, reconceptualization, and extension. Academy of Management Review, 27(2), 185 203. https://doi.org/10.4135/9781412956246.n1

Zahra, S., Sapienza, H., \& Davidsson, P. (2006). Entrepreneurship and Dynamic Capabilities: A Review, Model and Research Agenda. Journal of Management Studies, 43(June), 917-955. https://doi.org/10.1111/j.14676486.2006.00616.x

Zhang, J., \& Wu, W.P. (2013). Social capital and new product development outcomes: The mediating role of sensing capability in Chinese high-tech firms. Journal of World Business, 48(4), 539-548.

https://doi.org/10.1016/j.jwb.2012.09.009

Intangible Capital, 2020 (www.intangiblecapital.org)

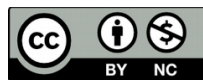

Article's contents are provided on an Attribution-Non Commercial 4.0 Creative commons International License. Readers are allowed to copy, distribute and communicate article's contents, provided the author's and Intangible Capital's names are included. It must not be used for commercial purposes. To see the complete license contents, please visit https://creativecommons.org/licenses/by-nc/4.0/. 